\title{
The Aggiornamento of the Irish Catholic Church in the 1960 s and 1970s
}

Yann Bevant

\section{(2) OpenEdition \\ 1 Journals}

\section{Electronic version}

URL: http://journals.openedition.org/etudesirlandaises/3902

DOI: $10.4000 /$ etudesirlandaises.3902

ISSN: 2259-8863

Publisher

Presses universitaires de Rennes

\section{Printed version}

Date of publication: 20 November 2014

Number of pages: $39-49$

ISBN: 978-2-7535-3559-6

ISSN: 0183-973X

\section{Electronic reference}

Yann Bevant, "The Aggiornamento of the Irish Catholic Church in the 1960s and 1970s ", Etudes irlandaises [Online], 39-2 | 2014, Online since 20 November 2016, connection on 19 April 2019. URL : http://journals.openedition.org/etudesirlandaises/3902 ; DOI : 10.4000/etudesirlandaises.3902 


\title{
The Aggiornamento of the Irish Catholic Church in the 1960s and 1970s
}

\author{
Yann BevanT \\ Université Rennes 2 - UEB
}

Abstract

The Irish Roman Catholic Church was affected by deep and far-reaching changes from the early 1960s to the late 1970s. The turning point which led to a period of revision and to a reassessment of the sense of place of the Church in Irish society dates back to the innovations of Pope John XXIII and the second Vatican Council. Although other important factors were also at work, the sea change that could be observed in the Church's attitude strongly contributed to the emergence of a climate of freer discussion and encouraged politicians to push ahead with new legislation.

Keywords: aggiornamento, ecumenism, Irish Roman Catholic Church, John Charles McQuaid, ultramontanism

\section{Résumé}

L'Eglise catholique d'Irlande a connu des bouleversements profonds entre le début des années 1960 et la fin des années 1970. Le moment clé qui conduisit à une période de révision et de questionnement quant à la place et au rôle de l'Église catholique dans la société irlandaise remonte aux réformes introduites par le pape Jean XXIII, et plus particulièrement à l'influence de Vatican II. Bien que d'autres facteurs aient également joué un rôle important, la transformation considérable de l'attitude de l'Église dans cette période contribua fortement à l'apparition d'une atmosphère beaucoup plus propice au débat, qui encouragea les hommes politiques à poursuivre et approfondir l'effort d'adaptation de la législation irlandaise rendu nécessaire par la fin des doctrines et politiques protectionnistes.

Mots clés : aggiornamento, oecuménisme, église catholique d'Irlande, John Charles McQuaid, ultramontanisme

The census carried out in 1961 revealed that 95\% of the population in the Republic of Ireland was Roman Catholic. Though it is commonplace to argue that on an all-Ireland basis religious affiliation was far from being so homogeneous, there is no doubt that Ireland could be considered a Catholic stronghold, all the more so since an overwhelming majority - about $90 \%$ of the Catholic population - went to church at least once a week ${ }^{1}$.

1. D. Keogh, "The Role of the Catholic Church in the Republic of Ireland 1922-1995", p. 85-213 in Building 
From the 1960s onwards, Ireland began to experience a marked change in attitude on a number of crucial issues, not least of all economic policies. The end of protectionism in the late 1950s, early 1960s, was a U-turn in ideological terms for the Irish State, which would have deep and long-lasting consequences. By the early 1960s the Irish began redefining their national identity and Irish society underwent a process of secularisation.

The 1960s and 1970s were a turning point for the Irish people in their relation to Church and religion. As Whyte pointed out in his book Church and State in Modern Ireland 1923-1979, Catholic social teaching remained very active but less ideological ${ }^{2}$. In fact it could be argued that the Church became more concerned with the actual needs of people and far less with the growing importance the State assumed in social fields which had heretofore been considered Church territory, as the famous crisis erupting from Noel Browne's Mother and Child Scheme epitomized at the beginning of the 1950s. Although strong episcopal opposition to the scheme may not have been the only reason why it was eventually dropped, the influence of the bishops in the process can hardly be denied "the bishops denounced State healthcare for all mothers and children as a 'ready-made instrument for future totalitarian aggression ${ }^{3}{ }^{\prime \prime}$.

The Fianna Fáil government which took over after the fall of the Costello administration in 1951 also had to take into consideration objections made by the Catholic hierarchy when it came to health and welfare matters, as the difficult negotiations which led to the Health Act of 1953 suggest. Whyte argues that:

The most obvious feature of Irish Catholicism in the late 1940s was a mood of increasing "integration". All sorts of forces were at work to make Ireland a more catholic State than it had yet become, more integrally committed to catholic social teaching as then understood, more totally committed to catholic concepts of the moral law, more explicit in its recognition of the special position of the Catholic Church. There was nothing surprising in such a development; this had been the direction of thrust in Irish history ever since independence, and it was in these years that the process reached its culmination ${ }^{4}$.

Alongside the work of conservative associations and periodicals involved in the Catholic social movement, an organisation known as Maria Duce began to develop. Maria Duce was established in 1945 and thrived on the edge of the

Trust in Ireland, Studies commissioned by the Forum for Peace and Reconciliation, Belfast, The Blackstaff Press, 1996, p. 153.

2. J.H. Whyte, Church and State in Modern Ireland 1923-1979, Dublin, Gill and Macmillan, 1980.

3. R.F. Foster, Modern Ireland 1600-1972, London, Penguin, p. 572.

4. J.H. Whyte, Church and State in Modern Ireland 1923-1979, p. 158-159. 
Catholic social movement. Maria Duce was probably the most integralist movement in Ireland in that period. At this stage a definition of what is meant by integralism. Whereas Christian Fundamentalism is defined as "the belief that everything in the Bible is completely true" (Collins Dictionary), integralism is the belief that faith can only be lived out in an integral way, which means that the Church is expected to teach its precepts integrally and does not depart from them under any circumstance, and the faithful have to respect those precepts fully. $\grave{A}$ la carte Catholicism, in other words, is not an option.

Chubb described Maria Duce as "more papal than the Pope". In fact the aim of the association was to organise society as a whole along vocational lines so as "to avoid the pitfalls inherent both in the unbridled individualism favoured by capitalism and in the excessive State control sponsored by communism"

This view does not seem much different from the teaching of contemporary popes such as John Paul II or Benedict XVI. However, it must be added that in its own newspaper, FIAT, the association denounced Bolshevism, Jews, Freemasons, and supported Senator Joseph McCarthy's witch hunt in America. Last but not least, one of Maria Duce's main goals was the amendment of article 44 of Bunreacht na Eireann which acknowledged the special position of the Catholic Church. The association wanted the article to be rewritten as such: "The One True Church divinely appointed to teach Man what favours or hinders his supernatural destiny ${ }^{7}$.

Maria Duce did for a time enjoy the recognition of John Charles McQuaid, the Archbishop of Dublin who exerted strong influence over the articles on family, marriage and education when Bunreacht na Eireann was being drafted. Indeed, it must be remembered that Maria Duce attracted the support of thousands, but this recognition did not last, as Chubb pointed out: "Some politicians or political parties were waiting for a signal from the bishops. It never came ${ }^{8}$."

It is quite interesting to note that an organisation such as Maria Duce could develop to the extent that it would benefit from some unofficial support from at least one top member of the Catholic hierarchy. Yet it was never fully endorsed, and its influence began to wane in the late 1950s. It survived into the early 1960s, and then disappeared altogether. In spite of the fact that Maria Duce - even at its highest - was not necessarily representative of the leanings of the Irish Catholic hierarchy, it is worth pointing out that it could at one stage exert some influence

\footnotetext{
5. B. Chubb, The Politics of the Irish Constitution, Dublin, IPA, 1991, p. 37.

6. D. Keogh, "The Role of the Catholic Church in the Republic of Ireland 1922-1995", p. 85-213 in Building Trust in Ireland, Studies commissioned by the Forum for Peace and Reconciliation, Belfast, The Blackstaff Press, 1996, p. 137.

7. B. Chubb, The Politics of the Irish Constitution, p. 41.

8. Ibid.
} 
both within and outside the Church, and its decline and fall corresponds to a period of change which tipped the scale in favour of more liberal views, not only in the Irish Church, but in the Roman Catholic Church as a whole.

In this regard it appears necessary to examine both the local and the international dimensions to fully grasp the interactions that were at work. The organisation of the Catholic Church cannot be limited to its Irish dimension as there are spiritual as well as political connections with Rome and through Rome with the outer world. Conversely the local context cannot be ignored as the Irish Church has its own specific history and its own specific issues: for instance, ecclesiastical and political jurisdictions do not coincide as the Irish Catholic Church is organised on the basis of a 32 counties Ireland, therefore it is the Irish Catholic hierarchy which makes decisions for the whole island. The Church is organised into 4 provinces (Armagh, Dublin, Cashel and Tuam) and 28 dioceses. In theory each diocese has a bishop though in reality some have had more than one, while others may depend from the bishop of another diocese: Dr Murphy, for instance, was bishop of Ross and Cork. But what makes Ireland quite specific is the parish structure. In the 1960s a French observer, Jean Blanchard, identified what it considered as the local nature of the Irish Catholic Church: "The bishop is a local, the clergy are locals and very often the religious men and women in a diocese are also locals?."

A consequence of this feature is that it is very easy for the members of the parish to identify with their priest and more generally with members of the clergy as they are fully-fledged members of the local and often rural community. The strength of the Church is therefore reinforced by the local nature of the clergy working in each parish. This is a feature Ireland has in common with Brittany, where practices at local level are sometimes reminiscent of the old Celtic Church: local saints who have not been sanctified by Rome are still honoured through processions and pardons celebrated by the local clergy, and traditions are more vivid in rural areas where communities are smaller and consequently more tightly knit. The following remark made by Tom Inglis would have well described the situation in Brittany in the early 1960s: "The priest in Ireland is a spiritual and moral adviser who is consulted on a wide range of social, political and economic issues [...] informally he is the most respected member of the community ${ }^{10}$ " Indeed in Breton a Catholic priest would be called a person, a word inherited from French which translates both the deference and the importance attached to his place in the community. The tightly

9. D. Keogh, "The Role of the Catholic Church in the Republic of Ireland 1922-1995”, p. 150.

10. T. Inglis, Moral Monopoly: The Catholic Church in Modern Irish Society, Dublin, Gill and Macmillan, 1987, p. 42 . 
knit communities also contributed to yet another striking feature: the strength and vitality of local associations ${ }^{11}$.

But why should we pay attention to such comparisons between Ireland and Brittany? Because in spite of the parallels we can make between the two, a difference also worth being noted is that in Brittany secularism à la française contributed to create a clear-cut divide between secular associations and associations more or less controlled by the Church. In Ireland a very large number of associations were connected to the Church, as no secularism à la française existed or was encouraged by the State. As a consequence, associations both at local and national level very much contributed to maintaining and spreading a Catholic social order. Organisations such as Muintir na Tire ${ }^{12}$, the Catholic Workers' college, social orders' summer schools, played an important part in the process. In the 1940s and 1950s for instance rural weeks were organized by Muintir na Tire so that attendees could discuss the problems affecting the Irish countryside and suggest solutions. In the early 1950s more than 50 parishes sent representatives to Muintir's rural weeks.

Other organisations or associations would develop a teaching of a rather - or sometimes very - conservative variety, as it was the case with Christus Rex, a society created in 1946, or Regnum Christi, the Catholic young men's society. The network at local level was therefore well-developed and well spread, and contributed not only to reinforce the Catholic social order but also to maintain and foster conservative views in vocational structures and organisations.

The changes which took place in Ireland between the late 1950s and the late 1970s were the result of a combination of several factors, both at international and local levels, but the main push for change came from outside, and from the top of the Church with Pope John XXIII. Pope John's pontificate began in 1958. The new Pope launched the process of Aggiornamento, that is to say a process which would enable the Church to adapt to the evolutions and meet the requirements of modern society and of the new economic and social order which emerged from World War Two. His encyclical Mater et Magistra was first released in 1961. Just like Pius XI's encyclical Quadragesimo Anno, it concentrated on social questions, and in spite of John XXIII's numerous references to the previous encyclical, there are major differences between the two documents, particularly with regard to State power and relations between State and Church. Whereas Quadragesimo Anno strongly advocated very limited State intervention in social matters, Mater et Magistra acknowledged the notion that the State had an extensive social role to play:

11. See also J. Rohou, Catholiques et Bretons toujours? Feizh ha Breizh Atao? Essai sur l'histoire du christianisme en Bretagne, Brest, Dialogues, 2012.

12. [http://lxoa.wordpress.com/category/muintir-na-tire/]. 
The present advance in scientific knowledge and productive technology clearly puts it within the power of the public authority to a much greater degree than ever before to reduce imbalances which may exist between different branches of the economy or between different regions within the same country or even between the different peoples of the world. It also puts into the hands of public authority a greater means for limiting fluctuations in the economy and for providing effective measures to prevent the recurrence of mass unemployment. Hence the insistent demands on those in authority - since they are responsible for the common good - to increase the degree and scope of their activities in the economic sphere, and to devise ways and means and set the necessary machinery in motion for the attainment of this end [...] a sane view of the common good must be present and operative in men invested with public authority. They must take account of all those social conditions which favor the full development of human personality. Moreover, We consider it altogether vital that the numerous intermediary bodies and corporate enterprises [...] loyally collaborate in pursuit of their own specific interests and those of the common good ${ }^{13}$.

Mater et Magistra can be seen as Rome's response to the changes brought about by the end of colonialism, the Cold War, the advent of Keynesianism and the emergence of the Welfare State in the Western world. The Catholic social movement gradually evolved along the lines of the new encyclical, all the more so since the main development of John XXIII's pontificate was the second Vatican Council which he convened in 1962 and which was to last until 1965. Though Pope John did not see its conclusion as he died in 1963, his name remains associated to this Council. What characterized the Council was the spirit of openness as many new themes - and sometimes controversial themes given the doxa of the Church- were discussed: the role of lay people in the Church, ecumenism, relations with other Christian churches and other faiths and creeds, to name but a few. As Desmond Fennell wrote in The Changing Face of Catholic Ireland: "The Council took us by surprise, discussion has been vigorous, our relationship to religion and our consciousness of the Church have changed greatly in a few years ${ }^{14}$."

It must be underlined that the changes brought about from the top of the Church by Vatican II also corresponded to a time of doubt and crisis in the Irish Church, which experienced the beginning of a fall in vocations. If the nuns, priests and brothers represented half of the teaching staff in secondary

\footnotetext{
13. [http://www.vatican.valholy_father/john_xxiiilencyclicals/documents/hf_j-xxiii_enc_15051961_mater_en.html], paragraphs 54 and 65.

14. D. Fennell, The Changing Face of Catholic Ireland, London, Chapman, 1968, p. 207.
} 
schools in 1961, their number dropped to $16 \%$ by $1983^{15}$. Furthermore, minorities who used to keep quiet and silent started to become vocal and outspoken, thus challenging the traditional ethos of Catholic society and morality. In 1974, David Norris launched the Irish Gay Rights movement, which aimed at reforming legislation on homosexuality. The Protestant minority and women activists were instrumental in the debate on the repeal of the laws against contraception: in December 1973, the Supreme Court ruled in the McGee Vs Attorney General case that the law prohibiting contraception was unconstitutional because it violated Mrs McGee's rights. As a result importation of contraceptives was decriminalized. There had been signs of the oncoming changes as early as the late 1950s: in 1956 INTO (the Irish National Teachers Organization) opposed the decision of the bishop of Killala who had decided to hand over control of a primary school staffed by lay people to a religious order. The struggle lasted until 1962 and a compromise was eventually reached through the mediation of the then Education Minister, Dr Patrick Hillery. Up to that period the power of the Church had been unchallenged in the field of education which was widely acknowledged as Church territory on moral and spiritual grounds. The provisions of the new encyclical clearly paved the way to the 1962 State mediation, which was a breakthrough ${ }^{16}$. The relationship was no longer a matter of Church and faithful, but of employer and employees.

Faced with changing social attitudes and behaviours, a decline in vocations, and the consequences of Mater et Magistra and Vatican II, the Irish Church of the 1960s and 1970s had to call itself into question so as to adjust to a rapidly changing environment both at home and abroad. As Joseph Lee puts it:

Periods of change always pose particular problems for churches which must cater for all their flock, not merely conservatives alone, or progressives alone ${ }^{17}$.

Much debate went on in the Church, which in turn led to a new direction in policy and to the emergence of new figures in the hierarchy. Members of the clergy began to question the role of the Church in Irish society, and even their own place in the Church. Carole Coulter in The Hidden Tradition reports the fact that some nuns came to challenge their subordinate role within the Church,

15. M. Goldring, « déclassement, reclassement des valeurs nationales », p. 125-132 in Études irlandaises, juin 1993, n'XVIII, p. 129.

16. "In the majority of cases a man's work is his sole means of livelihood. Its remuneration, therefore, cannot be made to depend on the state of the market. It must be determined by the laws of justice and equity. Any other procedure would be a clear violation of justice, even supposing the contract of work to have been freely entered into by both parties". [http://www.vatican.valholy_father/john_xxiiilencyclicals/documents/hf_jxxiii_enc_15051961_mater_en.html].

17. J. J. Lee, Ireland 1912-1985, Politics and Society, Cambridge, Cambridge University Press, 1989, p.655. 
criticized the patriarchal traditions of the Church and urged it to become more involved in the concerns of the poor ${ }^{18}$. In 1976, a priest argued in The Furrow a Catholic periodical edited and published in Maynooth - that Catholics need not be opposed in all circumstances to legislation on divorce ${ }^{19}$. This change, if not sharp shift of attitude, was also perceptible in the network of Catholic associations, as Trócaire ("mercy" in Irish) was created in 1973 with the support of a large section of the hierarchy. If Trócaire professed to be involved in social work as a Catholic society, its views of a Catholic social order were much different from those held by the conservative associations of the 1940s and 1950s, as Trócaire criticized the ...State for not doing enough ${ }^{20}$.

The evolution of mentalities was also encouraged by an alteration in the balance of strength between conservative and progressive members of the hierarchy. In 1971 John Charles McQuaid's resignation was accepted by Pope Paul VI and archbishop McQuaid formally relinquished the government of his archdiocese in February 1972. John Charles McQuaid was archbishop of Dublin, and his influence was considerable ${ }^{21}$. During his term a massive expansion of the Catholic Church took place in Dublin, and McQuaid was very active in the fields of education and charity. In 1941-1942 he was the architect of the Catholic Social Welfare Conference and of the Catholic Social Welfare Bureau. The late John Feeney wrote in the biography published in 1974 that McQuaid: "was a first class bishop of the old school ${ }^{22}$." Indeed, McQuaid had been trained and taught in a Church that was still under the influence of Cardinal Cullen's ultramontanism, and he took a special interest in French theology. Francis Xavier Carty casts an interesting light on John McQuaid in his 2007 book:

Though he was above all loyal to the Church and to the Pope and introduced the changes in the liturgy, there is no doubt that he was less than enthusiastic about the new policy of the Roman Catholic Church, and rather sarcastic as to the eventual changes it would bring about: his famous sentence 'no change will worry the tranquility of our Christian lives', while it can be considered as an attempt to reassure his flock, also reads as a very conservative declaration ${ }^{23}$.

18. C. Coulter, The Hidden Tradition, Feminism, Women and Nationalism in Ireland, Cork, Cork University Press, 1993, p. 47.

19. [http://archive.catholicherald.co.uk/article/11th-march-1977/2/sackings-at-maynooth-may-cause-strike]. Last accessed 24/05/2014. See also J. Whyte, Church and State in Modern Ireland 1923-1979, p. 403.

20. [http://www.trocaire.org/whatwedolforty-timeline. Last accessed 24/05/2014]. See also J. Whyte, Church and State in Modern Ireland 1923-1979, p. 355, p. 395.

21. Keogh and Chubb among others have contributed to show his influence in the drafting process of many articles of Bunreacht na Eireann, such as those on the family, marriage, and education.

22. J. Feeney, John Charles McQuaid: The Man and the Mask, Dublin, Mercier Press, 1974, p. 78-79.

23. F.X. Carty, Hold Firm: John McQuaid and the Second Vatican Council, Dublin, Columba Press, 2007, p. 126. 
McQuaid's praise of the Holy Faith nuns in a conversation with the bishop of Galway, Michael Brown, is even more telling: "The nuns will do anything to aid a parish priest. They are untouched by modern craze for Aggiornamento ${ }^{24}$."

John Charles McQuaid was replaced as archbishop of Dublin by Dr Dermot Ryan who, the next year, held an interdenominational service in Dublin during the Christian Unity week. Quite obviously, as the example of Dermot Ryan illustrates, the coming of age of a new generation who was taking the reins of the Irish Church contributed to smooth the path in Ireland for the policies springing out of the Aggiornamento. As Garet FitzGerald put it in 1972 : "The 1970s no longer saw consecration converting liberal priests into conservative bishops ${ }^{25}$."

Dr Tomás O'Fiaich, who became archbishop of Armagh in 1977 and a cardinal in 1979, belonged to this new generation. He committed himself to the cause of a united Ireland and was ready to accept a number of changes deemed necessary to bring about reconciliation between north and south. In particular he was one of those who argued from within the Church in favour of a clear-cut separation between Church and State by advocating that clergymen should not be in any way involved in trying to bring pressure to bear on legislators ${ }^{26}$.

Within twenty years Ireland experienced a sea change in the relations between Church and State. When he became Taoiseach in 1948, John Costello sent a message to the Pope as de Valera had done in 1932. His message assured the Pope of "our filial loyalty and our devotion [...] as well as our firm resolve to be guided in all our work by the teaching of Christ ${ }^{27 "}$.

In 1969, as the debate on article 44 of Bunreacht na Eireann acknowledging "the special position of the Holy Catholic Apostolic and Roman Church" was gaining momentum, Cardinal Conway declared: "I personally would not shed a single tear if the relevant subsections of article 44 were to disappear. It confers no legal privilege whatever on the Catholic Church and if the way to convince our fellow Christians in the North about this is to remove it, then it might be worth the expense of a referendum ${ }^{28}$."

The reasons that led to a rapid evolution of the Irish Church in the 1960s and 1970s are manifold, and have roots both inside and outside Ireland. The second Vatican Council unquestionably played a major part in the process by destabilising the guardians of the ultramontane tradition, and by prompting the emergence of progressive bishops. Vatican II also strongly contributed to open up the debate at grassroots levels and to facilitate the emergence of a network of progres-

\footnotetext{
24. Ibid., p.120.

25. G. FitzGerald, Towards a New Ireland, London, Charles Knight, 1972, p. 99-100.

26. See Enda Mc Donagh, "Cardinal Tomàs O’Fiaich, people’s priest”, in The Tablet, p.44, 19 May 1990”.

27. D. Keogh, "The Role of the Catholic Church in the Republic of Ireland 1922-1995”, p. 130.

28. See B. Chubb, The Politics of the Irish Constitution, p. 50.
} 
sive charities and associations that would not necessarily understand and promote the Christian social tradition the same way previous societies had done. As the lay members of the Church became more audible and sometimes more vocal, the crucial importance of their involvement must be taken into account: the 1960s and the 1970s presided over the beginning of a crisis of vocations in Ireland. Cardinal Conway's standpoint is also a reminder of the fact that this period coincides with the beginning of the Troubles in Northern Ireland, which if we take Conway's words at face value suggests that the Troubles also contributed to a reassessment of the notion of Irishness among Irish clerics.

Yet another factor which explains the Aggiornamento is not the debates within the Catholic Church: the pressure of the new macroeconomic and social policies pursued in the western world were more than a catalyst, as they literally drove the Roman Catholic Church out of its traditional territories of health, social affairs and education. Quadragesimo Anno, although mainly a response to the economic slump of the early 1930s, was still very much influenced by ultramontanism. Mater et Magistra heralded a much less stiff and proselytic Church, ready to come to terms with a changing world where it would have a moral and social role to play, but where it would not seek moral hegemony, nor social and political leadership. This new trend was confirmed by Cardinal Cahal Daly on the occasion of the New Ireland Forum debates in 1984:

The Catholic Church totally rejects the concept of a confessional State [...] the Catholic Church seeks only the freedom to proclaim the Gospel [...] We have repeatedly declared that we in no way seek to have the moral teaching of the Catholic Church become the criterion of constitutional change or to have the principles of Catholic faith enshrined in civil law ${ }^{29}$.

The 1980s nevertheless witnessed a conservative backlash, epitomized by the rise of organisations such as SPUC (Society for the Protection of the Unborn Child), by the No Divorce campaign in 1983, and by the concern voiced by important members of the hierarchy, all signs that many Catholics were uneasy at how things were going too $\mathrm{far}^{30}$. The set of reactions that could be observed at the time would call for further investigation: conservative thinking obviously thrived

29. New Ireland Forum Debates. Also reported in N. Collins and F. McCann, Irish Politics Today, Manchester, Manchester University Press, 1989, p. 102.

30. Catherine Maignant in her article "Strategies to save Globalized Secular Society", recalls Archbishop Dermot Ryan's address at Notre Dame de Fourvières in Lyons in 1983, in which he lamented the "pernicious influences from without" which led to the "loss of ancestral wisdom" and entailed Ireland no longer deserved the title of island of saints and scholars. (Catherine Maignant, "Strategies to save Globalized Secular Society", in Y. Bevant, E. Maher et al. (eds), Issues of Globalisation and Secularisation in France and Ireland, Peter Lang, Frankfurt, 2009, p 124-125. 
on issues still very sensitive in an Ireland which was becoming one of the most open economies in the world, and where patterns of lifestyle would not evolve evenly. Besides, as Catherine Maignant suggests, conservatives could expect at least moral support from Rome, where John Paul II had launched his new evangelisation strategy ${ }^{31}$. However, further developments which occurred in the 1990s, with the abortion debate following the X-case scandal and the end of the constitutional ban on divorce in particular, clearly signaled that there would be no going back.

The rise of the Celtic Tiger coincided with the emergence of more individualistic and materialistic values and behaviour, which in turn are being questioned today, now that the illusion of an ever affluent society has faded away since the beginning of the crisis in 2008. In the meantime, after the shock of the Murphy and Ryan reports ${ }^{32}$, Irish Catholics have also had to come to terms with the fact that "the age of $[\ldots]$ craven deference is [...] over", to quote Professor Ronan Fanning ${ }^{33}$. This "craven deference" started to fade away long before the reports were published, and even before the advent of the Celtic Tiger. The spirit of Aggiornamento strongly contributed to a change of mind in Catholic Ireland which at the same time marked the beginning of the end for the ways and principles inherited from Cardinal Cullen's days, and it also heralded a new era of openness and more liberal thinking both outside and within the Church in pre-Celtic Tiger Ireland. The most enquiring spirit that emerged in Ireland as a result of Aggiornamento was a precondition for the evolution of the Irish Catholic Church and acceptance by clergy and faithful to face and confront the failures and abuse of power outlined in the Murphy and Ryan reports.

31. Ibid., p. 134.

32. See [http://www.justice.ielen/JELR/Part\%202.pdfIFiles/Part\%202.pdf, and http://humanrightsinireland.wordpress.com/2009/12/08/murphy-commission-report-and-the-criminal-law/ Last accessed 24/05/2014].

33. Ronan Fanning, "The Age of our Craven Deference is Finally Over", The Irish Independent, 6 December 2009. See also [http://www.independent.ielopinion/analysis/the-age-of-our-craven-deference-is-finally-over-26588891. html]. Last accessed 24/05/2014. 